\title{
Syed Manzoorul Islam's Postmodern Tales: A Study
}

\author{
Md Abdul Momen Sarker \\ Department of English, World University of Bangladesh (WUB), Bangladesh \\ Email: sarker1@english.wub.edu.bd \\ Tusar Talukder \\ Department of English and Modern Languages, Central Women's University (CWU), Bangladesh \\ E-mail: tusar.talukder@gmail.com \\ Tusar Talukder (Corresponding author) \\ Department of English and Modern Languages, Central Women's University (CWU), Bangladesh \\ E-mail: tusar.talukder@gmail.com
}

Doi:10.7575/aiac.alls.v.7n.5p. 157

URL: http://dx.doi.org/10.7575/aiac.alls.v.7n.5p.157
Received: 18/06/2016

Accepted: 21/08/2016

\begin{abstract}
The paper brings into focus how Syed Manzoorul Islam, in his three-decade-long literary career, has mastered a narrative style that sets him apart from many of his Bengali contemporaries. It demonstrates all the traits unique to his storytelling: blurring of boundaries between dream and reality, self-reflexivity, irony, and humor. The research also encapsulates how Syed Islam is different from his contemporary short story writers in terms of constructing plot and character. It foregrounds the author's capability of developing a diction which is completely his own. The paper discusses the postmodern features prevailing in his stories. It shows us how the author invites the readers to be a part of his discourses. It summarizes the author's surrealist imagination which creates a world that is strangely familiar and unfamiliar at the same time. Overall, the research analyzes how the postmodern elements relate to the major themes of Syed Manzoorul Islam's short stories.
\end{abstract}

Keywords: Post-modernism, magic-realism, realism, psychoanalysis, political degeneration

\section{Introduction}

"Syed Manzoorul Islam's stories challenge our imagination as they traverse the realms of reality and dreams in order to incorporate the fantastic into the literal. In his stories, facts jostle with fiction to construct a space that is ultimately humane."

Debesh Roy

Syed Manzoorul Islam (1951- ) is one of the influential fiction writers in Bangladesh. He has been writing short stories and novels since 1988. He can be considered one of those few Bengali authors who are used to penning postmodern fiction. Syed Islam has enriched the genre of short story in many ways. Apart from writing fiction, he loves to write literary essays and art criticisms. Though he is well-versed in writing on a number of literary genres, he simply considers himself a storyteller. He generally tells his tales maintaining the age-old tradition of Bengali oral-narratives. In this regard, while coming across his stories one can easily discover a number of similarities between the narrative styles of Syed Manzoorul Islam and boom-time littérateur Gabriel Garcia Marquez. Consequently, the resemblance of a very rich tradition of storytelling between the culture of Bangladesh and that of Latin America can easily be found in his stories. Furthermore, magic realism has become an integral part of Syed Islam's stories. The magical happenings of his stories take us to a world where reality and magic go hand in hand. Through his stories the author gives us a view into the lives of ordinary Bangladeshis who struggle to make their ways in the world. All his brilliant postmodern short stories have been written in the last three decades. The article minutely analyzes Syed Islam's narrative style, the major themes and characters of his stories and the postmodern techniques he has applied in constructing the plots.

\section{Storytelling of Syed Manzoorul Islam}

In case of storytelling, Syed Manzoorul Islam employs his surrealist imagination. The narrators of his stories continuously talk to readers and prepare them for the twists and turns the stories take. When the stories begin, readers are invited to become the narrators' co-travelers and they take the readers to a world where the boundaries between dream and reality blur. Moreover, like Garcia Marquez, Syed Islam frequently moves from one viewpoint to another. A book review published in The Daily Star mentions: "If one goes through Marquez's One Hundred Years of Solitude and Islam's Shukhdukher Galpo (Stories of Happiness and Sorrows) he/she will surely find some elements of similarity in those books, particularly magic realism, surrealism and meta-fiction. However, both Syed Islam and Garcia Marquez 
have dealt with these matters through maintaining their distinctive styles. Syed Manzoorul Islam's style of storytelling is very frank and incisive." A reviewer says the following words regarding the narrative style of Syed Islam:

Professor Islam's narrative style in the stories is refreshingly innovative which adds significantly to their charm. Reading his stories is like being on a journey where the narrator is constantly interacting with his companion, that is, the reader taking him/her along the road with him and allowing them to experience the array of emotions that the characters themselves feel. The reader is made to empathize with different human conditions as they reveal themselves at different twists and turns of the narrative. The narrator often asks them questions, encouraging them to reflect on the incidents that unveil as if in front of their eyes and engaging them deeply in the plot of the narrative. The reader might feel amused, upset, elated, exhilarated, relieved or even indignant as the author sheds light into the deep recesses of the human mind that only he is privy to. Much of his style undoubtedly has its origin in the oral tradition of story-telling where the story teller is as much an omniscient narrator as part of the story itself. (Basu, 2014)

\section{Background}

Syed Manzoorul Islam's writings got a large readership in Bangladesh and West Bengal, India. Almost all happenings of his tales bear a symbolic tone. However, this symbolization does not create any obstruction for the readers to perceive the inner meanings of his discourses. Since the author generally writes his stories based on real life incidents, most of the plots have a clear resemblance to the practical happenings of everyday life. In this regard, a review brings into focus the following lines: "He writes about what has happened in his world and of what he has heard from others. This message flows to readers again and again. He seems to be inviting readers to be part of his discourse." Unusual or bizarre happenings of Syed Islam's stories always draw a special attention to readers. So, the author does not get surprised to deal with strangeness of life. Rather, he invariably blends surrealistic contents with real events of life. And he strongly believes that "the surreal is the flip side of reality - it is what gives meaning to our everydayness." (S. M. Islam, personal communication, April 19, 2012). For instance, in the story "Kathal Konya" (The Jackfruit Maiden), Absar, a major character, informs the writer that he has seen a girl emerging from inside a large jackfruit. The following excerpt from the story will clarify the aforesaid discussion:

The jackfruit glowed with light-it was no longer bright, yellow and brown, but white, or fair, like a girl. The jackfruit looked strangely alive. If you were in my place, Sir, you'd certainly feel that the jackfruit was a fair and slim looking girl, slowly taking her clothes off...sorry Sir, and was glowing under a full moon that shone directly on her bare body. And he was calling you, beckoning you like a glowing lighthouse... sorry Sir, sorry Sir. I was afraid, I couldn't look. You know Sir, those creatures we call succubus-what's the plural for it Sir? But never mind-well Sir, they, the succubuses or succubae alone have the power to call you out of your house on nights like this and devour your flesh, blood and soul... while you lie in a deep stupor or in a sleep of death. (Islam, 2013)

However, it does not seem strange to the author, for he has grown used to writing stories based on such surrealistic content. This type of bizarre incident helps readers perceive how magic reality deserves a special place in our normal life.

\section{Diction}

Syed Manzoorul Islam's diction distinguishes him from his other contemporary fiction writers. The diction of his tales is fat-free, artistic and facile. The unique power of using words appropriately in his stories gives him a special ability to discover the inner strength of the words. For example:

Then came the day which grandmother wanted to treat differently than other days. She cooked my grandfather's favourite pabda aadajamir-the pink pabdas were so big that their ends stuck out the plate. She also cooked a selection of vegetable delights: spinach paneer, stuffed orka in curds, potato-pataldalna, besides the usual bhartas and bhajis. (Islam, 2013)

To globalize the local words the author has not translated the Bengali words such as pabda (name of a sea fish), potatopataldalna (mixed vegetables) etc. Moreover, he never tries to lengthen his sentences unnecessarily. Indeed, the lyrical quality of his sentences depicts a consistency of theme.

\section{People of His Stories}

Syed Islam's stories are peopled with the people from every walk of society. The stories bring into focus different problems of the individuals. His tales analyze the causes prevailing behind the on-going political unrest in Bangladesh. The stories explore the psychological abnormalities and economic dilemmas of people's life. His narratives, through an in-depth analysis of the characters, unveil the predicament of urban life. The absurdities of urban lifestyle find a special place in his stories. The characters that have given life to his stories include students entangled with existential crisis, service holders burdened with over responsibilities, young men involved in extra marital affairs, terrorists immersed in 
depression and so on. Moreover, the stories excavate the happenings such as how a robber turns into a billionaire, how some idealistic men's dreams shatter etc. Indeed, Syed Islam draws a real picture of the society he is a part of. In fact, Islam dwells on the mystique that is humanity. He approaches realism from the perspective of postmodernism, juxtaposing present and past. He is also capable of exposing the conscious as well as subconscious aspects of the human mind. Consequently, the elements of realism and surrealism prevail side by side in his stories.

\section{Postmodern Techniques}

What comes first to appraise Syed Islam is the plain but playful language he has woven in his stories. He has frequented the diction, which is his own, only to be ascribed to a minimalist. The form of his stories also obtains from him the effective experimentation. His exploration among the characters exhibits before the readers the crystal-clear ins and outs of the characters, which proves him a maximalist in character developing. The development of traditional characters is a rarity in his short stories and he has offered his peoples of the stories the entire liberalism to express themselves. The interplay of multivalent literary genres such as the narrative thriller, detective, realist, psychological and the like are opulent in Syed Islam's stories, positioning him in the auspicious arena of literature. Stream of consciousness is another complicit literary flair embellished in his stories. It turns the tough task for the readers to identify the real protagonist or hero or villain in most of his stories, implying another formidable feature of postmodernism. In addition, a fusion of high and low culture is visible in some of his stories. And this feature has helped readers differentiate post-modern stories from those of other ages. His postmodern stories are pregnant with a new dimension derived from our cultural elements and some moral implications.

\section{Major Themes}

Some stories of Syed Islam can be discussed to justify the above mentioned features of his postmodernism. Enam, Miah, a worker in Hossain Miah's garage, in "Daedalus-er-Ghuri" (Daedelus's Kite), a story from Prem O Prarthonar Galpo (Stories of Love and Prayer), flies a kite in ignorance of his master Enam Miah, though he knows his father died flying kites. Flying kites is nauseating to Hossain Miah himself for flying kites killed his brother as well. Journalist Abdul Mueed Talukder gives his Vespa to Hossain Miah to restore its disordered parts. Despite being on holiday Hossain Miah puts Mueed Bhai's Vespa back in order because the journalist had saved this garage from the furious clutches of the mayor's henchmen. And thus the story moves on. Setu Miah, commonly known as an expert in making kites, is compared with Daedelus of Greek mythology by the writer. The picture of prevailing political pollution with its vacuum accentuated in "Daedalus-er-Ghuri" (Daedelus's Kite), exhibits Islam as a percipient onlooker of the contemporary politics and indicates that the general masses are completely hostage to political degeneration. It is the modern man's segregated and lonely life, which is another postmodern feature, elicited in his story.

Again in "Tara Vabhe Tara Saap Ashole Tara Rozzu" (They Pose They are Snakes, but They are Ropes), Syed Islam structures the character Wakilur Rahman as an idealistic one who fights all the ills of contemporary politics. The author detects that the gradual degradation of morality and the lack of proper political philosophy are the main impediments to building a healthy political culture in Bangladesh. In fact, the character symbolically projects the philosophical thoughts of Syed Islam. In the same story, the author develops a character, unnamed, to show the real picture of the rotten politics of Bangladesh. The nameless character is Wakilur Rahman's brother-in-law who used to involve in politics. But as a politician he does not possess strong morality and ethics. As a result, he flees once Operation Clean Heart (a special drive launched by the Bangladesh Army and other law enforcers to detain criminals) gets underway countrywide. Here the author holds forth on the thought that if people had accepted philosophy not merely as a subject but as a totality of life-defining principles, then Operation Clean Heart might not have been promulgated to net the wicked.

Syed Islam's latest volume of short story entitled Bela Obelar Galpo (Stories of Good Times and Bad Times), a collection of thirteen stories, can be dissected to understand the author's postmodern experimentation. The stories resemble the experiences the author has experienced. Thereupon, the readers find the tales close to their everyday happiness and grief. We generally encounter a lot of good and bad times throughout our life. Those events of life are full of happy and sad moments. Stories emerge from those good and bad moments. In Bela Obelar Galpo (Stories of Good Times and Bad Times), Syed Islam has attempted to explore those moments which we cannot forget. One of such type of stories is "Brishtir Din" (The Day of Rain) which shows two girls, Sutapa and Kona, being from two different places. They go through the various troublesome phases of their life but never surrender to the situations. Syed Islam shows us how two girls reach a satisfactory level at one stage of life through overcoming a plenty of unexpected and cruel forces of society. Again, in a part of the story, Sutapa has a deep feeling for her own community and country and, on the other hand, Kona too has intense love for school children whom she once taught but was compelled to leave them in order to get rid of a crisis. Their feelings indicate a common love for their roots delineating Islam's deep love for localness. This love for localness is a quintessential feature of postmodern literature. In a word, this story informs us how Sutapa and Kona, by changing themselves, change the lives of the other characters who encounter them. At the end, the tales of two girls merge into one.

Since the author has taken his characters from different walks of life, the lives of four terrorists are portrayed in one of his stories titled "Char Santrashi" (Four Terrorists). The storyteller tells us how four terrorists, namely Badi, Alfaz, Mati and Sumon, lead a nomadic life by adopting every possible destructive ways. Dhanu Miah, who is a smuggler, deals in drugs with the help of those four top terrorists. Dhanu Miah does not even hesitate to trade his first wife for the sake of smuggling. Dhanu Miah's second wife Farhana loves a man named Limon Miah. She always has an image of Limon Miah before her, especially when Dhanu tries to have sex with her; she dreams that Limon is having sex with her. Farhana always tries to find the alternatives to lead her life but the four terrorists together with Dhanu Miah never 
attempt to seek any alternative way to come back to normal life. Finally, the four terrorists face death due to excessive drinking. However, the ending part of the story brings into focus how terrorism slowly leads people to a life where there is no way out. Furthermore, if in the story "Uddhar" (Rescue)in childhood Nazim, owner of Nehal Group of Industries, lost his younger brother, Nehal, whom he loved most. Nehal was only 12 . The waves of the sea submerged him. But still now Nazim looks for his lost brother. One day while going to Cox's Bazar, his car collides with a truck but due to the hard brake of the truck driver, Nazim along with his driver survives. Afterwards, with the help of a police officer, they ride in a bus where Nazim hears from a girl that she is also looking for her brother, who has been kidnapped. Now she is going to rescue him to get information about his present stay from a source. To hear the story, Nazim phones his son, Nafis, informing him that Nehal has been traced and he has to be rescued. Nazim replaces Nehal with the girl's lost brother.

Moreover, coming across the story "Nei" (Absence) the readers observe that Syed Manzoorul Islam has related the same tale from three separate viewpoints, purporting to show how different characters feel someone's absence differently. The story "Sodh" (Revenge) is about an intelligent girl, Urmi, who takes revenge on her opponents by applying some tricky ways. Hakim Ismail, father of Urmi, demonstrates some magical happenings with the assistance of his daughter to drive away his foes from the village. Coming across a lot of deceptive actions, readers will find the characters of the tale devoid even of an iota of honesty. At the end of the story, we can discover how some characters use technology negatively for deception, delusion and perversion. Again, Shikar, (Victimization) which can be termed as a story of mystery, is the story of a banker describing juxtaposing his past and present time and in this way he is excavating his past memories. At his workplace, he encounters a girl, Monira, who is a new employee at his bank. She informs him that she is from Duri Angur Lane, an area of old Dhaka city. Hearing the name of the lane he trembles with fear because he used to go to a house of that lane for the purpose of tuition when he was a student of Jagannath University. To teach a lady, almost double his age, he faces a lot of unexpected, indecent and dubious kinds of activities performed by the lady. For instance, one day the lady, by force, kisses him at the time of teaching. This type of adulterous attachment between the teacher and the lady student helps us discover many unknown and unexplored regions of human being's life. In fact, the author, through the story, has explored some unexplored arenas of our everyday life.

Most of the stories of Bela Obelar Galpo (Stories of Good Times and Bad Times) deal with such themes as shattered dreams of individuals, crisis of existence, mismatch between beliefs and practices, predicament of urban life, individual psychological issues, and chronological degradation of moral sense and so on. In the case of a number of stories in Bela Obelar Galpo (Stories of Good Times and Bad Times), it is assumed that the story teller is telling two tales simultaneously within a story. In fact, the tales told by Syed Islam are very graphical. Furthermore, Syed Manzoorul Islam, as in his previous collections, has ably exposed the conscious and subconscious aspects of the human mind through the portrayal of the characters of this collection. His sense of humor is so intense that even while narrating a serious matter, he can infuse humor into it without disturbing the harmony of the tale. And with his characteristic humorous presentation, he takes readers into grotesque realities. In this regard, Bijoy Lal Basu says: "Professor Islam's subtle sense of humor, which is aided by his minute observation of people with all their follies and mannerisms, pervades most of the stories keeping the reader fresh and fully engaged in the narrative". Since the diction he employs in the stories is fat-free and facile, he can easily invite readers to be part of his discourse. Needless to say, his stories bear vivid signs of his scholarship in literary as well as cultural theories.

In recent times, Syed Manzoorul Islam himself has translated some of his Bengali stories into English. The Daily Star Books has published those translated stories as a book entitled The Merman's Prayer and Other Stories. The stories discussed in this paper have also been positioned in the book. Except those in The Merman's Prayer and Other Stories, some other stories have also been discussed in this article to decipher how Syed Manzoorul Islam has infused magical realism into his stories. Since magic realism has been an integral part of postmodern literature Syed Islam has aptly used it in some of his stories of this collection. For example, the story "The Silk Handkerchief" indicates the husband of the young girl, who is being taken away to Dhaka by a crooked relative, finally comes to his senses and comes riding a white Arabian horse and rescues her from the clutches of the old pervert. On the other hand, Ferguson Dinnerwala takes revenge on his ungrateful son by appearing in his dream. The story titled "Extramarital" is about the narrator himself whose great grandparents come to his apartment one summer night and the mysteries surrounding his family history begin to unfold before him. Then in "The Merman's prayer" the fugitive youth finds love in a mermaid who emerges from the sea at midnight and has romantic conversations with him. The rendezvous between them grow frequent and the man decides to join her in the sea by becoming a merman himself. In a review of this book, Bijoy Lal Basu brilliantly comments on the dealing of Syed Islam's magical realism with some of his stories. His comment accentuates Syed Islam's deft use of magic realism in two of his interesting stories:

One also encounters the paranormal as in the story titled "The Jackfruit Maiden" where Mia Afsar is haunted by a girl who comes out of a jackfruit and goes back into it leaving him hypnotized and dazed. The paranormal is also present in "The Ground Beneath Paritosh's Feet" where Rehana Banu, a woman who lost her child during childbirth, now feasts on children in her dream. (Basu, 2014)

In all these stories, magic realism and the paranormal are presented very skillfully alongside the normal in a realistic setting with the result that the reader is willing to suspend disbelief and move along with the narrative. 


\section{Conclusion}

The above analysis of Syed Manzoorul Islam's stories creates a holistic view of life. As a storyteller, he shows us the life we lead is pregnant with normal and paranormal happenings. His characters come from the fringes of society as well as from the urban middle class, and are drawn with compassion, understanding and power. The desires and deprivations, their ecstasies and frustrations are all presented in a narrative which is magical and lucid at the same time. A reviewer mentions:

He has captured the vast arena of human life on a tiny canvas, demonstrating the truth that life consists of a fullness of variety. His fiction speaks against social hypocrisy and thuggery, the heart-rending repression of women and the dishonesty of those who trade in religion. He depicts the great sorrows of small people. At the same time he gives us hope and helps us dream of the noble and the beautiful. Syed Islam's sense of proportion regarding the use of words and the diction he develops in his works are magnificent manifestations of his literary imagination. As an innate storyteller, he demonstrates the power of his storytelling. (Basu, 2014)

Overall, the paper, through an analysis of the stories, explores those vital ingredients of our everyday life which are less explored.

\section{References}

Basu, B. L. (2014, March 25). Magic of storytelling. The Daily Star, 13. Retrieved from http://www.thedailystar.net/magic-of-storytelling-17129

García, M. G. (2006). One Hundred Years of Solitude (G. Rabassa, Trans.). New York: Harper Perennial Modern Classics.

Islam, S. M. (2013a). The Merman's Prayer and Other Stories. Dhaka: The Daily Star.

Islam, S. M. (2013b). Bela Obelar Galpo. Dhaka: Prothoma Prokashan

Islam, S. M. (2012). Sukh Dukhher Galpo. Dhaka: Nymphea Publications.

Islam, S. M. (2005). Prem O Prathonar Galpo. Dhaka: Annyadin.

Miller, L. (2004, July 16). The war for the soul of literature. Salon. Retrieved from http://www.salon.com/2004/07/15/peck_wood/

Surreal: Flip side of reality. (2012, April 19). Retrieved from http://timesofindia.indiatimes.com/lifestyle/books/features/Surreal-Flip-side-of-reality/articleshow/12648413.cms?

Talukder, T. (2011, June 18). Syed Manzoorul Islam: Tales of the Postmodern. The Daily Star, 13. Retrieved from http://archive.thedailystar.net/newDesign/print_news.php?nid=190368. 